\title{
Pre-travel health advice for human immunodeficiency virus- infected travelers, from Rio de Janeiro
}

\author{
Aconselhamento pré-viagem para os viajantes infectados pelo vírus da \\ imunodeficiência humana no Rio de Janeiro
}

\author{
Ricardo Pereira Igreja ${ }^{1}$
}

\begin{abstract}
Counseling for human immunodeficiency virus infected travelers is becoming increasingly specialized. Previous studies have reported the experience of HIV-infected travelers from temperate-climate countries but little is known about HIV-infected travelers from tropical countries. A retrospective study was conducted on HIV-infected travelers presenting at a travel health clinic in Rio de Janeiro. Eleven journeys by ten people were recorded. Brazil (Amazon region and Northeast) was the destination for six journeys. Other destinations were Peru, Angola, Europe and Asia. Nine attendees were undergoing antiretroviral therapy. Few HIV-infected people from Rio de Janeiro consulted a travel medicine specialist before traveling. Since they travel to destinations in Brazil and abroad where there are endemic diseases not encountered in Rio de Janeiro, careful pre-travel planning needs to be undertaken. Strategies for increasing the frequency of pre-travel consultations need to be developed, such as closer collaboration between HIV clinics and travel health clinics.
\end{abstract}

Key-words: Travel medicine. Human immunodeficiency virus. Rio de Janeiro. Brazil.

\section{RESUMO}

0 aconselhamento para os viajantes infectados pelo vírus da imunodeficiência humana está se especializando cada vez mais. Estudos prévios relatam a experiência dos viajantes infectados pelo vírus da imunodeficiência humana dos países de clima temperado, mas pouco se sabe sobre os viajantes infectados pelo vírus da imunodeficiência humana dos países tropicais. Foi realizado um estudo retrospectivo dos viajantes infectados pelo vírus da imunodeficiência humana que consultaram um serviço de medicina de viagem no Rio de Janeiro. Dez viajantes realizaram onze viagens. 0 Brasil (Amazônia e Nordeste) foi o destino de seis viagens. Outros destinos foram Peru, Angola, Europa e Ásia. Nove pacientes estavam sob terapia antiretroviral. No Rio de Janeiro, poucas pessoas infectadas pelo vírus da imunodeficiência humana consultaram um especialista em medicina de viagem antes de viajar. Como elas viajam para destinos no Brasil e no exterior aonde existem doenças endêmicas não encontradas no Rio de Janeiro, deve-se realizar um planejamento cuidadoso antes da viagem. Devem ser desenvolvidas estratégias para aumentar a freqüência das consultas pré-viagem, como, por exemplo, uma colaboração mais próxima entre as clínicas de vírus da imunodeficiência humana e de medicina de viagem.

Palavras-chaves: Medicina de viagem. Vírus da imunodeficiência humana. Rio de Janeiro. Brasil.

Travel Medicine is an exciting interdisciplinary specialty that has developed rapidly in response to the needs of the traveling population worldwide. The development of Travel Medicine as a discipline is a recent advance in itself. This has been recognized in the United Kingdom by the Department of Health in its new strategy for combating infectious disease, which confirms the need for specialists in travel medicine ${ }^{26}$. The field of Travel Medicine has grown dramatically, as a greater number of people travel to exotic and remote destinations. Approximately 600 million travelers cross international borders annually. However, studies suggest that only about $8 \%$ seek pre-travel health advice, and

\footnotetext{
1. Preventive Medicine Department, Medical School of the Federal University of Rio de Janeiro, RJ, Brazil.

Address to: Dr. Ricardo Pereira Igreja. Rua von Martius 325/608, 22460-040 Rio de Janeiro, RJ, Brazil.

Tel: 5521 2512-7812, Fax: 5521 2590-5422

e-mail: rpigreja@cives.ufrj.br

Received in 02/07/2008

Accepted in 02/06/2009
}

many receive information from practitioners who are ill-equipped to provide current and accurate information. Travel Medicine has become increasingly complex due to dynamic changes in global infectious disease epidemiology, changing patterns of drug resistance, and a rise in the number of travelers with chronic health conditions ${ }^{12}$. In general, the risk of becoming ill during international travel depends on the region of the world visited, as well as factors such as age, health status, length of stay and planned activities. To reduce the risk of illness or injury abroad, a healthcare provider should be consulted, ideally $4-6$ weeks before international travel. Additionally, children, the elderly, pregnant women and immunocompromised travelers may be particularly vulnerable to certain problems while traveling and may require more specialized counseling 5 . Since the introduction of highly active antiretroviral treatment (HAART) in 1996, there have been substantial reductions in deaths and hospital admission rates in the developed nations. Increasing numbers of HIV-infected people are back in work and are traveling for holiday, family or business reasons ${ }^{13}$. Patients with CD 4 counts below $200 / \mu l$ are at substantial 
risk of opportunistic infections, which can be acquired both in an everyday environment and through travel. Furthermore, the effectiveness of vaccinations in this group of patients is reduced ${ }^{25}$. Traveling to tropical and subtropical countries significantly increases the chance of coming across infectious organisms ${ }^{19}$, but Furrer found that visiting tropical countries was associated with a lower risk of progression to acquired immunodeficiency syndrome (AIDS), indicating that traveling is a proxy for good health ${ }^{8}$. The total number of people with AIDS in Rio de Janeiro is over $30,000^{21}$. Although Rio de Janeiro is a city located in the tropics, tropical diseases are not a major problem in Rio, except for dengue, and vaccine-preventable diseases like polio or measles were eliminated in 1988 and 1999, respectively ${ }^{21}$. Previous studies have reported the experience of human immunodeficiency virus (HIV)-infected travelers from temperate countries ${ }^{381013}$. This study reports findings from a public travel clinic for HIV-infected people living in Rio de Janeiro, Brazil.

\section{MATERIAL AND METHODS}

This study was carried out at Cives, the Travel Clinic of the Medical School of the Federal University of Rio de Janeiro, Brazil. Cives is the first public health information center for travelers in Brazil and it was the only one in Rio de Janeiro at the time when this study was performed. Consultations and vaccines were free of charge. A retrospective study of HIV-infected travelers presenting at the clinic from 2002 to 2006 was undertaken. The following information was analyzed: age, sex, CD4+ T-lymphocyte count, antiretroviral therapy, vaccinations, reason for traveling and travel destination.

\section{RESULTS}

A total of eleven journeys by ten people were recorded. All of these individuals lived in Rio de Janeiro and there was just one woman. Their ages ranged from 33 to 48 years. The reasons for travel were business (63.5\%) or holidays (36.5\%). Brazil was the destination for six journeys (54.5\%) and Peru, Angola, Georgia, Uzbekistan and Switzerland were the destinations for one journey each (9.1\%). In Brazil, the destinations were the Amazon region (four times) and the northeastern coast (twice). Nine attendees were undergoing antiretroviral therapy. The CD4 count ranged from 200 to $842 / \mu l$. The vaccines prescribed were for hepatitis B (four times), Vi typhoid, tetanus/diphtheria (three times each), yellow fever, Salk polio, influenza (twice each), hepatitis A, pneumococcal disease, rabies and meningitis (once each).

\section{DISCUSSION}

We examined the pre-travel preparation among HIV-infected attendees at a travel clinic, which differs from other studies that were performed among HIV-infected travelers attending HIV clinics $^{381013}$. Travel Medicine is a new branch of medicine in
Brazil; the number of travel clinics is still limited; and people are not used to looking for this before traveling. This may explain the small sample size of patients, which is a limitation of our study.

Pre-travel consultation in travel clinics has been shown to decrease the rate of illness during travel ${ }^{7}$. It is quite clear, however, that travel clinics can only be effective if travelers use them. In Quebec, Canada, there are almost a hundred travel health clinics offering preventive services to travelers for a population of around seven million, but only around $15 \%$ of Quebecois travelers who are at risk consult a travel clinic ${ }^{16}$. One study conducted in London found that just $11 \mathrm{HIV}$-infected individuals sought pre-travel medical consultations ${ }^{3}$ and another study in the USA found that only one HIV-infected patient consulted a travel medicine expert before traveling ${ }^{11}$. Experts generally bemoan the low attendance rates at travel clinics and many strategies have been suggested for increasing the frequency of pre-travel consultations ${ }^{7}$.

Although many clinicians attending HIV-infected patients are specialists in infectious and parasitic diseases, some of them may not feel able to advise travelers. Before evaluating individuals at pre-travel consultations, clinicians have the responsibility that they must determine their own limitations. A threshold should be set for when a referral might be made to a Travel Medicine specialist, considering the traveler's best interests and the need to provide the most complete and up-to-date information ${ }^{5}$. Travel advice for HIV patients is becoming an increasingly specialized field and there have been good reviews on this subject ${ }^{1924}$. In the present study, about half of the travelers were referred by just one doctor at our Medical School who was aware of the problem.

While European studies only reported on travel to destinations abroad $^{38}$ and an American study showed that only $26 \%$ of the HIVinfected patients traveled within the USA ${ }^{10}$, we found that $54.5 \%$ of the journeys were in Brazil, and 36.4\% were to the Amazon Region. The majority of the 500,000 cases of malaria reported in Brazil every year are from the Amazon Region ${ }^{18}$.

Although earlier reports did not find any association, evidence that HIV infection and malaria interact with one another has been accumulating more recently ${ }^{9}$. The data available suggest that there is probably no interaction between the nucleoside reverse transcriptase inhibitors and malaria drugs.

The common drugs used for malaria prophylaxis are chloroquine, mefloquine, doxycycline and atovaquone/proguanil. No clinically significant interaction is expected between nonnucleoside reverse transcriptase inhibitors and these drugs. All protease inhibitors (PI) inhibit hepatic cytochrome p450 enzymes, and they share this behavior with many antimalarials. Ritonavir, the most potent inhibitor of cytochrome P450 3A4 (CYP3A4), does not increase mefloquine levels, but the plasma ritonavir levels are decreased by mefloquine ${ }^{19}$. Coadministration of lopinavir or ritonavir and atovaquone may result in decreased concentrations of atovaquone. The clinical significance of this is unknown, but an increase in the atovaquone dose may be needed ${ }^{23}$. No clinically significant interaction is expected among protease inhibitors, except between ritonavir, chloroquine and proguanil.

Quinine, artemisinin and lumefantrine are used for treatment of malaria. Quinine is extensively metabolized by CYP3A4. The 
exposure may be increased by ritonavir or ritonavir-containing boosted PI regimens. Quinine either is contraindicated or has to be used with great caution. Careful monitoring of drug levels to avoid fatal arrhythmias is necessary. Artemisinin, and its derivatives such as artesunate and artemether, are rapidly metabolized via CYP3A4 to a biologically active metabolite, dihydroartemisinin.

Although the parent drugs and dihydroartemisinin all have antimalarial activity, dihydroartemisinin has greater potency than the parent drugs. Inhibition of CYP3A4 would reduce dihydroartemisinin, but increase the concentrations of the parent drug and potentially increase the half-life of the parent drug. The effects of protease inhibitors and non-nucleoside reverse transcriptase inhibitors are unclear ${ }^{23}$. Lumefantrine is extensively metabolized by CYP3A4. Lumefantrine does not seem to prolong the QT interval and is much safer than halofantrine. Nevertheless, interactions with PIs and non-nucleoside reverse transcriptase inhibitors (NNRTIs) are likely and the manufacturer's summary of product characteristics advises that coadministration with CYP3A4 inhibitors is contraindicated ${ }^{23}$.

Mucocutaneous leishmaniasis is also a major problem in the Amazon region, and Leishmania-HIV coinfections have been reported in Brazil ${ }^{9}$. Although Brazil managed to validate interruption of vector-borne transmission of Trypanosoma cruzi by Triatoma infestans by the year $2006^{14}$, oral transmission of Trypanosoma cruzi is still possible and outbreaks caused by the juice of Euterpe oleraceae (a fruit that grows in the Amazon region) have been described ${ }^{6}$. Reactivation of Chagas disease is in the list of AIDS-defining disease in Brazill ${ }^{20}$.

Yellow fever vaccine is contraindicated in cases of symptomatic HIV infection'. In our study, among the travelers to the Amazon region, two were given vaccination $(\mathrm{CD} 4>350 / \mu \mathrm{l})$, one had already been vaccinated and one was not vaccinated for yellow fever. One British study ${ }^{3}$ found that no HIV-infected patients were vaccinated for yellow fever, even though $12 \%$ of them traveled to Africa. Shaw and Leggat ${ }^{22}$ described an expedition to the Amazon region in which they found that there were few tropical illnesses, most likely because of the considerable effort put into health preplanning and disease prevention. Therefore, pre-travel health advice from a travel clinic is vital for HIV-infected people traveling to the Amazon region.

Travel to other countries was reported five times. One traveler went to Cuzco, Peru, which is located at an altitude of $3,326 \mathrm{~m}$ above sea level. Acetazolamide is an acceptable prophylactic medication against altitude sickness for travelers visiting areas over the altitude of $2,500 \mathrm{~m}$ above sea level ${ }^{2}$. Allergic reactions to acetazolamide are extremely rare, but this drug is related to sulfonamides and should not be used by sulfa-allergic individuals 5 . Acetazolamide may be used with caution for HIV-infected patients since side effects relating to trimethoprim-sulfamethoxazole have been noted in only $10 \%$ of the patients without HIV infection, but in about $50 \%$ of HIV patients ${ }^{1}$.

Many travelers visiting Cuzco engage in casual sexual activities that put them at risk of acquiring and transmitting sexually transmitted diseases ${ }^{2}$. In Germany, an estimated 5 to $10 \%$ of HIV infections are acquired during holidays. HIV-positive travelers should be aware of the special risks that sexually transmitted diseases and HIV superinfection present to them ${ }^{25}$. Travel- associated HIV infections are mainly caused by non-B subtypes and circulating recombinant forms, which contribute towards increased HIV-1 diversity. This increase has in turn led to the emergence of new recombinant forms. Increased HIV-1 diversity has implications for diagnostic and treatment efficacy (although the data remain limited), and for future vaccine programs ${ }^{15}$.

There was one journey to Switzerland. Although developed countries have low rates of vaccine-preventable diseases, outbreaks of measles and mumps were recently reported in Switzerland, Germany, Spain and USA, mainly among unvaccinated individuals ${ }^{4}{ }^{17}$. Measles, mumps and rubella vaccines are not recommended for HIV-infected persons with evidence of severe immunosuppression 5 .

Food and waterborne diseases are endemic in Angola. Salk polio vaccine is preferred in relation to oral polio vaccine for HIV-infected patients because of the risk of paralytic poliomyelitis associated with oral polio vaccine in these patients ${ }^{19}$. The Vi typhoid vaccine should also be chosen in preference to the live oral typhoid vaccine. Reduced immunological defenses and diminished gastric acid production increase the risk of gastrointestinal infections in HIV patients. Travelers must strictly observe proper water and food hygiene ${ }^{25}$.

One person traveled twice: the first time to Georgia and one year later to Uzbekistan. Cases of diphtheria have declined after the massive outbreak of the 1990s in the newly independent states ${ }^{5}$.

If a person seeks a travel health provider for immunization for travel, this should be an opportunity to administer other vaccines when the recommendations have not previously been carried out ${ }^{5}$. Since seven of the attendees had previously been vaccinated for preventable diseases that exist in Rio de Janeiro, e.g. hepatitis B, hepatitis A, pneumococcal infection, tetanus and diphtheria, and at least eight had previously had measles (data not shown), only a few people were vaccinated at the pre-travel consultation.

Other vaccines like yellow fever, typhoid, polio and rabies have been indicated for journeys. One study found that individuals traveling to Africa received vaccination for hepatitis $A$ and $B$ and typhoid but not for others that are recommended ${ }^{3}$.

Nine travelers were receiving HAART with CD4 counts over $200 / \mu \mathrm{l}$. If, in the pre-HAART era, many patients traveled when they were in a severely immunosuppressed condition with a strong desire to take their last chance to trave ${ }^{10}$, nowadays many HIVpositive travelers have benefited from advances in antiretroviral therapy. They present increased survival, better quality of life and reduced risk of opportunistic infections ${ }^{19}$.

One recent study (in which $79.4 \%$ of travelers were undergoing antiretroviral therapy) found a median CD4 count of 451/ $\mu l^{3}$. However, in a British study, 27 (11.3\%) individuals stopped their antiretroviral treatment at the time of travel. Among these 27 who discontinued their treatment, only 15 (55.5\%) sought medical advice before stopping antiretroviral treatment and one individual developed an NNRTI-based mutation ${ }^{13}$.

Furthermore, in our study, business was the reason for travel in $63.5 \%$ of the cases, in contrast to $15 \%$ in an earlier study ${ }^{10}$. This is a sign that HIV-infected individuals are living and working as well as non-infected people. 
Our data suggest that many HIV-infected people from Rio de Janeiro travel to destinations in Brazil and abroad where there are endemic diseases not encountered in Rio. Like HIV-infected travelers from other countries, veryfew of them consulted a travel medicine expert before traveling. As seen in previous studies ${ }^{3}$, pre-travel preparation for HIV-infected travelers needs to be carefully planned and carried out, including vaccination, prophylactic medications and advice regarding safe food, drink, conduct and lifestyle behavior. HIV-infected patients need to be more aware that medical counseling prior to traveling is necessary. It is hoped that the results from this study may lead to closer collaboration between HIV clinics and travel health clinics.

\section{REFERENCES}

1. Bartlett JG, Gallant JE. 2001-2002 Medical Management of HIV infection. Johns Hopkins University, Division of Infectious Diseases, Baltimore, p. 290, 2001.

2. Cabada MM, Maldonado F, Quispe W, Serrano E, Mozo K, Gonzales E, Seas C, Verdonck K, Echevarría JI, Gotuzzo E. Pretravel health advice among international travelers visiting Cuzco, Peru. Journal of Travel Medicine 12:61-65, 2005.

3. Cathcart S, Boyle J, Sabin C, Johnson M, Zuckerman JN. Pre-travel preparation and outcome of HIV-infected travelers from a UK clinic. Travel Medicine and Infectious Diseases 1:114-118, 2003.

4. Centers for Disease Control and Prevention. Measles - United States, 2005. MMWR Morbity Mortality Weekly Report 55: 1348-1351, 2006.

5. Centers for Disease Control and Prevention. Health Information for International Travel 2008. US Department of Health and Human Services, Public Health Service Atlanta, 2007.

6. Coura JR, Junqueira ACV, Fernandes 0, Valente SAS, Miles MA. Emerging Chagas disease in Amazonian Brazil. Trends in Parasitology 18:171-176, 2002.

7. Duval B , De Serre G, Shadmani R, Boulianne N, Pohani G, Naus M, Rochette L, Fradet MD, Kain KC, Ward BJ. A population-based comparison between travellers who consulted travel clinics and those who did not. Journal of Travel Medicine 10: 4-10, 2003

8. Furrer H, Chan P, Weber R, Egger M, the Swiss HIV Cohort Study. Increased risk of wasting syndrome in HIV-infected travelers: prospective multicentre study. Transactions of the Royal Society of Tropical Medicine and Hygiene 95: 484-486, 2001.

9. Harms G, Feldmeier H. The impact of HIV infection on tropical diseases. Infectious Diseases Clinics of North America 19:121-135, 2005.

10. Kemper CA, Linnet A, Kane C, Deresinski C. Frequency of travel of adults infected with HIV. Journal of Travel Medicine 2:85-88, 1995.
11. Kemper CA, Linett A, Kane C, Deresinski SC. Travels with HIV: the compliance and health of HIV-infected adults who travel. International Journal of STD \& AIDS 8:44-49, 1997.

12. Kozarsky PE, Keystone JS. Body of Knowledge for the Practice of Travel Medicine. Journal of Travel Medicine 9:112-115, 2002.

13. Mahto M, Ponnusamy K, Schuhwerk M, Richens J, Lambert N, Wilkins E, Churchill DR, Miller RF, Behrens RH. Knowledge, attitudes and health outcomes in HIVinfected travellers to the USA. HIV Medicine 7: 201-204, 2006.

14. Pan American Health Organization. $X V^{\text {th }}$ Meeting of the Southern Cone intergovernmental commission to eliminate Triatoma infestans and interrupt the transmission of transfusional trypanosomiasis (INCOSUR - Chagas). Brasília, Brazil, 6-9 june 2006. [accessed on March 12, 2007]. Available from: http://www.paho.org/English/AD/DPC/CD/dch-incosur-xv.htm

15. Perrin L, Kaiser L, Yerly S. Travel and the spread of HIV-1 genetic variants. Lancet Infectious Diseases 3: 22-27, 2003.

16. Provost S, Gagnon S, Lonergan G, Yen-Giang Bui. Travel Clinics in Québec (Canada). Journal of Travel Medicine 13: 227-232, 2006.

17. Richard J, Masserey Spicher V. Ongoing measles outbreak in Switzerland: results from November 2006 to July 2007. Euro Surveill 2007; 12(7):E070726.1. [accessed on March 14, 2007]. Available from: http://www.eurosurveillance. org/ew/2007/070726.asp\#1

18. Santos MA, Czeresnia D, Souza-Santos R, Oliveira RM. Comportamento epidemiológico da malária no Estado do Mato Grosso, 1980-2003. Revista da Sociedade Brasileira de Medicina Tropical 39:187-192, 2006.

19. Schuwerk MA, Richens J, Zuckerman JN. HIV and travel. Travel Medicine and Infectious Diseases 4:174-183, 2006.

20. Secretaria de Vigilância em Saúde. National STD and AIDS Programme. Criteria for AIDS case definitions in children and in adults. 2004 Revision. Ministério da Saúde, Brasília, DF, 2004. [accessed on March 15, 2007]. Available from: http:// www.aids.gov.br/data/documents/storedDocuments

21. Secretaria Municipal de Saúde. Agravos de notificação. [accessed on March 14, 2007]. Available from: www.saude.rio.rj.gov.br

22. Shaw MTM, Leggat PA. Life and death on the Amazon: illness and injury to travelers on a South American expedition. Journal of Travel Medicine 10:268-271, 2003.

23. University of Liverpool. Drugs interaction charts. [accessed January 7, 2008]. Available from: [www.hiv-druginteractions.org/frames.asp?drug/drg_main.asp]

24. Van Gompel A, Kozarsky P, Colebunders R. Adult travellers with HIV infection. Journal of Travel Medicine 4:136-143, 1997.

25. Weitzel T. Traveling with HIV. In: Hoffmann H, Rockstroh JK, Kamps BS (eds) HIV Medicine 2006, Flying Publisher, Paris, p. 533-540, 2006.

26 Zuckerman JN. Travel medicine. British Medical Journal 325:260-264, 2002. 